\title{
Analysis on Social Management Innovation from the Perspective of Grassroots Democratic System
}

\author{
Xuehai $\mathrm{Hu}$ \\ School of Marxism \\ Hohai University \\ Nanjing 210098, China \\ xuehai1976@hhu.edu.cn
}

\author{
Chenchen Zhang \\ Department of Marxism Leninism \\ Shijiazhuang University \\ Shijiazhuang, 05000, China \\ zc9c9@163.com
}

\begin{abstract}
- the democracy at the grassroots level is a important composition of Chinese characteristic socialism democratic politics. Democracy at the grassroots level in our country after reform and opening up has been rapidly developed, which can ensure the effective performance of people's political rights and promote the development of politics and government innovation. Current China is being in economic and social transition period, which requests to resolve social contradictions, enhance social cohesion through the system of social management innovation so as to promote the co-construction and share development of a harmonious society. Only continuing to promote the construction of democracy at the grassroots level of institutionalization and develop grassroots democracy in the breadth and depth, can we combine the government, society, with people effectively and realize the continuing advance of the social management innovation.
\end{abstract}

\section{Keywords-democracy at the grassroots level, Decentralization; Social management;}

\section{INTRODUCTION}

Democracy Politics is not only one of the most important characteristics of modern politics, also the basic framework of the power operation and political relations in modern country. It is the consensus of the source of legitimacy of public power and mode of operation on the basis of the social political practice and summary on the historical experience in human society. Democracy at the grassroots level plays a crucial role on effective exercise of social management function of the government. The development of grassroots democracy has significance on the social management innovation. In recent years, our country has regard the democratic politics construction as the basic framework of the socialist political system with Chinese characteristics, and promoted vigorously the democratic construction of grass-roots development and construction of democracy and the rule of law, which can safeguard the rights of citizens, promote the welfare of the society and realize the people's interests.

\section{THE SCIENTIFIC CONNOTATION OF THE DEMOCRACY AT THE GRASSROOTS LEVEL IN CHINA}

Grass-roots democracy is not only an important part of the socialism system with Chinese characteristic, but also the basis for effective operation of democracy in our country.
In a word Grass-roots democracy is the fundamental guarantee for realizing the people being in power.

\section{A. The Fundamental Guarantee for Realizing the People Being in Power.}

Early in the revolutionary war, the leaders of

Communist Party of China were aware of the important role of the political democracy to protect people's rights and maintain regime stability and realize the prosperity of the country through absorbing the lessons of Chinese dynasties alternating and summarizing the construction experience of the Base of Revolution. After the founding of new China, through the planning for a few years, China produced the new China's first deputies at all levels by universal suffrage in most parts of the country in 1953, through extensive publicity and in-depth mobilization, which also opened a prelude to the development of grassroots democracy in china. But after the enlargement of the counter- right movement, the democratic atmosphere deteriorated inner-party centralism, such as democratic Centralism weakening, democracy is replaced by concentration, personal power expansion, China's grass-roots democracy had also been a great negative impact, which had finally brought great impact and destruction for the democracy and legal system in the Cultural Revolution. People were deprived of the constitutional political rights and people's legal rights can not be maintained and implemented.

\section{B. The Reasonable Distribution Pattern of the Social Interests.}

As an important political achievement of the development of human civilization, the democracy not only shows great vitality, also become more fair and reasonable distribution of social interest's pattern. The democratic system provides the most effective mechanism to solve people's all things. Through the development of more than 400 years, although there were still many shortcomings and weaknesses in practice, modern democracy had become not only an important political symbol of modern countries, also the pursuing goal with the universal significance of human society according to development status of international society in the twentieth century seventy or eighty. Similarly, for the highly centralized power and blind personality cult of China, democracy was more significant. There were numerous factors of bursting the great vitality in China in 
the thirty years of reform and opening up, but the political democracy is undoubtedly one of the most important elements. The free and tolerant social atmosphere of the democracy creating let the Chinese people have stood on one's own in mind and spirit and the awareness independence finally promoted the comprehensive and rapid development of China's economy and society over the 30 years of reform and opening up. Similarly, the democratic political expansion and the popularization of grass-roots democracy has also promoted the citizen consciousness growth, at the same time, democratic system also provides the channel which the masses of the people reflect their will, express legal appeals so as to effectively maintain the positive interaction between state and society after the Almighty political system collapsed.

\section{The Fundamental Way of Safeguarding People's Legitimate Rights And Interests.}

Most fundamentally, democracy at the grass-roots level is the fundamental way of having the broad masses people as the master of the country, participating to make the formulation of social interest's distribution and safeguarding their legitimate rights and interests. Especially in recent years, with the adjustment of the pattern of economic development in China and social benefits diversification trend, many social contradictions which covered by the rapid economic development first thirty years gradually had unfold and caused many problems, some of these even intensified group conflicts and cause extreme results, although these conflicts events mostly can smoothly calm. We can find through observation that grassroots democracy no favorable operation is a very important factor, even a fundamental factor which make the people not to effectively solve the interest distribution problem by legitimate way. Inversely, if grass-roots democracy construction is so more perfect that people's legal rights can be protected and people can negotiate the social benefits allocation through democratic politics, there is rare occurrence of malignant group incidents or extreme conflicts.

\section{THE SignifiCANCE OF PROMOTING THE} CONSTRUCTION OF SOCIALIST DEMOCRATIC POLITICS AND DEVELOPING THE DEMOCRACY AT THE GRASSROOTS LEVEL

\section{A. It is an Important Content of the Construction of Socialist Democratic Politics to Develop the Grassroots Democracy.}

After unremittingly long-term efforts, our party has made remarkable achievements and accumulated some successful experiences in the development of grassroots democracy. The enthusiasm and initiative of the broad masses of the people's political participation were improved greatly and the democratic rights of the masses were maintained effectively. The 17th National Congress clearly put forward four systems for the construction of socialist democratic politics, which is to adhere to and perfect the multi - party cooperation and political consultation system under the leadership of the Communist Party, regional national autonomy system, as well as the grass-roots mass self-government system [3]. The Communist Party of China clearly put forward to regard the grass-roots mass self-government system as one of the four system of socialist democratic politics, this shows that the development of grassroots democracy not only is an important content in accelerating China's socialist democratic politics construction, but also indispensable and irreplaceable in the process of the construction of socialist democratic politics.

\section{B. It is an important guiding principle for advancing the principle of building China's socialist democratic politics to develop democracy at the grassroots level.}

In the new period previous congress, the Party Central Committee has repeatedly stressed

the fundamental requirements for realizing China's working class and the masses of the people to exercise the power of economic and social affairs management and of nation administration, which is a fundamental requirement for the socialist democracy at the grassroots level. First to ensure their economic, political, cultural and other social affairs as a home to master is the foundation which the working class and the broad masses of people are in power for the country's economic, political, cultural and social life. It is the wide practice of socialist democracy and basic work of socialist democratic construction to extend democracy at the grassroots level, ensure people directly to exercise their democratic rights and manage their own affairs according to law. Only under the guidance of the Party's important strategic thought and guiding principle, the construction of grass-roots democracy in China can continue to develop and expand, move forward along the correct political direction. Finally, the working class and the masses of the people's political rights can be guaranteed effectively.

\section{The Development of Grassroots Democracy is an Important Platform to Improve People's Political Quality and Management Ability as Well as the Important Channel of Orderly Political Participation.}

Expanding socialist democracy is an important content of the construction of socialist democratic politics in China and democracy at the grassroots level is an important component of socialist democracy. Only the development of democracy at the grassroots level can ensure the broad masses of the people enjoy extensive democratic rights according to law practically so as to lay a key foundation for promoting democratic political construction of socialism, which have a solid platform and support for expanding socialist democracy. The development of grassroots democracy can ensure the masses of people to realize self-management, self-service, self-education, self supervision and to exercise democratic supervision over the cadres, which ensure the people to exercise directly their democratic rights according to law, arouse the people to participate political positively so as to make people to be master really and strengthen political quality and management capacity in political participation gradually. [4] 


\section{PROMOTING THE DEVELOPMENT OF GRASSROOTS DEMOCRACY IN ORDER TO PROMOTE THE INNOVATION OF SOCIAL MANAGEMENT}

The socialist harmonious society is the society in essence that every citizen has the participation right, every social member can enjoy the benefits of economic development and let each social member to achieve individual development in the social progress by increasing opportunities.

\section{A. Promoting the Development of Grassroots Democracy.}

After the reform and opening up, that the rapid development of Chinese economy and the rapid change of social structure has promoted social stratification and differentiation and the formation of different interest groups. But for a long time, in the face of various social interests structure, our country has not established the equilibrium and effective interests consultation and rights sharing mechanism, which the different social interest groups can not enjoy the same basic rights, express their willingness appeals and safeguard the interests so as to promote their opportunity and ability. There were many problems such as the rich and poor gap and the vulnerable groups made by the development of the market economy and social structure differentiation resulting in the institutional unfair - that the different groups between the rural and city, individual and society, within the system and outside the system exist the inequality of public service, social welfare and development opportunity. The social dividend of which the huge economic and social dividends was generated after the reform and opening up by system unfair not only can't share equal distribution in all social groups, but also blocked the channel of efficient expression of the interests groups for appeals and safeguarding their legitimate rights and interests, leading easily to social conflicts and groups incidents. Therefore, in the transition period of China's economic and social development, we must continue to promote the development of grassroots democracy, strengthen democratic construction of grass-roots democracy at the grassroots level so as to innovate the social management and to resolve social contradictions. We must construct the channels mechanism which the social groups of different interests expressed their interests appeals, coordinated interests relation and negotiated resource allocation equally and effectively, so as to realize the equal status of various social strata in politics and law and to increase the ability of social benefit groups equal safeguarding their legitimate rights and interests. Only we find the way of people's political participation, interests consultation and appeal expression through the development of grassroots democracy, which make the various social interest groups to reflect the will, to negotiate interest and to eliminate differences equally, can we realize the social solidarity and social cohesion, so as to promote the innovation of system and mechanism of social management.

\section{B. Promoting the Innovation of Social Management.}

The innovation of the social management pattern is the governance mode of which change the traditional mode of government undertaking social governance under the condition of the planned economy and creating various effective ways so as to help the masses of the people realize self management. It can adapt to the characteristics of social diversification and liquidity under the conditions of market economy. This social management patterns is the governance mode of 'small government, big society'. The innovation of social management mode is to arouse fully the enthusiasm and initiative of the masses. This also means that we must promote the transformation of the government so as to change the exercising scope and operating mode of the public power. Therefore, we must achieve the bold breakthrough in reform of social management system in order to support and encourage social organizations, civil organizations and the masses of the people to participate in the social management. Meanwhile, we must change traditional way of social management under the government monopoly and give full play the main role of the society and people, standardize the governmental power and promote the social autonomy, thus forming the virtuous governance situation of multi-party participation, consultation and communication, multiple subjects. In order to realize the innovation of social management, make the people to obtain more rights of autonomy and free space, and regulate the operation mode of the public power, we must develop democracy at the grassroots level vigorously and promote the construction of democratic politics, so as to make the masses of the people to express effectively their will and demand, to safeguard the legitimate rights and interests and to promote the public interest through the democracy channel. The political practice of more than thirty years of reform and opening has proved that the democracy at the grassroots level can play an important role of support and guarantee in the solution of social conflicts, the formation of social consensus, cohesion of social forces, promotion of the social development.

\section{The Development of Grassroots Democracy is the Essence of Social Management Innovation.}

Grass-roots democracy not only is the embodiment of Chinese people being in power,

but also is basic way of reasonable and effective allocation of social public interests and it is also the fundamental guarantee to achieve social stability and enhance the legitimacy of the government. At present, there has been the differentiation of social interests with a higher degree in China. The deferent social stratum and social groups have their own interests' appeal, which will become social contradictions and trigger the mass conflicts with the acquisition of limited resources competition. And the democracy at the grassroots level made the citizens to express conveniently their will through more direct and public participation by keeping the different views and sounds on a common platform. The democratic system also provides communication and consultation channels on the equality and tolerance base so as to form a consensus with compromise which all parties are acceptable. It is only consensus with compromise formed through democracy on allocation of social public interests agreement to obtain the 
acceptance and observance of different social groups, so as to safeguard the law's dignity and common observance of social norms, and to achieve social stability ultimately. Facing with the social contradictions and conflicts of interest, disregarding and ignoring these or forcible suppression through the power can not really solve the problem thoroughly. Only we admit and face different interest demands, respect and protect the equal expression and negotiation all parties through democratic channels, can we find a solution accepted widely for the society so as to achieve social stability and harmony.

That the development of democracy at the grassroots level and practical experience during 30 years in China, indicate again with sufficient evidence that Chinese not only understand the democratic politics, but also can effectively exercise the democratic rights by law to safeguard their legitimate rights and interests so as to achieve stability and unity of the society.

Therefore, for all levels of government especially the grass-roots government, in order to build the social environment of long-term stability and healthy function, we must face up various interest contradictions in the social development and fully respect for the will demands of the people masses. Meanwhile, we must e protect the citizens to exercise effectively the legal rights by the constitution and law through the democratic system. Only we have known and understood the great value of democracy and promote the development of China's socialist democratic politics in-depth, can we condensate effectively the social forces and won the trust and support of the masses of the people so as to draw the legitimacy resources from the support of the people.

\section{THE CONCLUSION}

Since the reform and opening up Chinese reform creation practice has proved that the democracy at the grassroots level could effectively combine the power of the government, social resources and the wisdom of the masses, let the people supervise fully the government administration and make the society to participate the public management which promote development of limited government, public administration and sunshine government, and relate closely with the government, the society people. Therefore, it is the essence of social management innovation development to promote the construction of institutionalization of democracy at the grassroots level and to promote the development of democracy at the grassroots level in breadth and depth, which make the society and citizens to obtain more independent authority and free space to protect the public interest, let the government carry out the public functions on the maintenance of order, security of rights and interests and service supply.

\section{ACKNOWLEDGEMENTS}

This work was financially supported by the central university's professional expenses of scientific research in Hohai University Project No.2009B 25914.

\section{REFERENCE}

[1] Bai gang, Zhao Shouxing: Elections and Governance: a study of villager autonomy in China. Chinese Social Sciences Publishing House.2001.

[2] He Zengke: The road map on the system reform of social management in China. National School of Administration press.2009.

[3] Zhou Yongkang: strengthening and innovating social management, establishing and perfecting social management system of the socialism with Chinese characteristics.2011:9.

[4] Document laboratory of Central Committee of the CPC: The activities of deeply studying and practicing the scientific outlook on development $[\mathrm{G}]$. Beijing: the party's publishing house, 2008:157-160.

[5] Wang Xixin. Public participation: the theory on the imagination of participatory democracy and system realization [J]. politics and law, 2008 (6).8-14. 